\title{
Fair Lady: effective coverage of politics in a women's magazine
}

\author{
Chanél Boshoff, Lynnette Fourie and Thalyta Swanepoel
}

\begin{abstract}
The article discusses the coverage of politics in South African women's magazine Fair Lady in selected years from democratisation in 1994 to ten years later in 2004. In a democracy, the media has the explicit duty to inform society. Within this context three questions are asked: (1) Which political themes are covered? (2) In what genres do the political items feature? (3) In what ways does the magazine focus the reader's attention on political items? These aspects were selected to provide a clear view of the extent and manner in which Fair Lady presents politics in its content. This study was done by means of a qualitative content analysis. By focusing on these issues and by drawing on the functions of the media; the agenda setting theory; the schema theory and the on-line evaluation theory, it is argued that the magazine deems politics as important and incorporates it on its agenda to provide readers with necessary political information which they might not otherwise attain. Fair Lady overcomes the fact that politics does not traditionally feature in women's magazines by taking care in attracting and keeping readers' attention to political items. The publication (especially in 2004) can be held up as an example to other women's magazines trying to fulfil their function as a medium to educate and inform readers whilst at the same time not alienating the entertainmentseekers.
\end{abstract}

\section{Introduction and problem statement}

People have the right to information that is in the public interest (Retief, 2002:239; Froneman, Swanepoel, T. \& Van Rooyen, G.M., 2005:2;49). Politics are certainly one of the most important aspects when it comes to public interest, in the light of the fact that it directly influences people's everyday lives. Politics shape and stimulate the development of dominant beliefs and opinions in society which in turn leads to the forming of a collective social identity and consciousness which again influences people's personal, everyday decision making and functioning (Odendal, 1994:809; Buckingham, 1999:178; Sreberny \& van Zoonen, 2000:13). In this article, 'politics' are broadly defined as the management of society by the participation of citizens and public officials as well as the management of people's ordinary lives by the application of certain principles that guide attitudes, beliefs, reactions and behaviour in situations relating to the public sphere. 
Thus, for a person to share in the political process, he/she must have command of certain information. One of the fundamentals of democracy is the enhancement of social and political conditions in which people are able to exercise their own choices (Oosthuizen, $2003: 133 ; 164)$. In order to make such choices and thus have more control over all aspects of their everyday lives, women are dependent on access to information and the ability to communicate on an equal level with other members of society.

The media stands central in this empowerment process. The normative functions of the media in the context of a democracy incorporate, amongst other things, the following: information relay and education, interpretation, analysis, persuasion, cultural continuity and socialisation, entertainment and mobilisation (Laswell, 1960:118-130; Lazarsfeld \& Merton, 1960:497-501; McQuail, 2000:79-80,495; Berger, 1995:121-124; Black, 1982:254-55). The functions of women's magazines are, in a broad sense, the same as those of the media in general. There are, however, different nuances in the manifestation of certain functions.

The cultural continuity function finds particular ground in women's magazines (Narunsky-Laden, 2007:596-7, Le Masurier, 2009). It helps females to form their identity as women. This happens during the process of gender socialisation by which women internalise the norms of femininity; that is the way in which women are 'supposed to' behave, by observing these norms from the content of the magazine. Women's magazines therefore play an important role in the formulation of gender roles in society and in this sense they can foster social change or perpetuate the status quo. Gender is defined as the sex category of an individual - female or male - and the behavioural characteristics associated with each (Berger, 1995:174). Even women who do not read women's magazines are indirectly influenced by the messages women's magazines send (Inness, 2004:124-126). It is clear then that the women's magazine serves as one of the 'role models' for the depiction of femininity and the perpetuation or adaptation of the norms thereof. It is in fact the rulebook of this collective idea of femininity (McQuail, 2000:80). Although the women's magazine is not solely responsible for the socialisation and education of women, it can have an impact on this lifelong process by excluding politics from their definition of femininity.

According to Heith (2005), although women's magazines are soft news 'outlets' that use sensational and personality-centred approaches to convey news, they emerged in the American 2004 election campaign as a 'full-fledged source of political information'. Heith goes on to say that although traditional media for conveying political media remains the most important, scholarly interest is turning toward new or non-traditionalist media, including the women's magazine.

In line with this and to recap: media messages influence the individual to make decisions with regard to the values and general views that rule in the society in which they find themselves (De Beer, 1998:14). The research of many different authors (Fourie, 2004:13; Sotirovic \& McLeod, 2001:286; Hendriks Vettehen, P.G.J., Hagemann, C.P.M. \& Van 
Snippenburg, L.B. 2004:421; Sreberny \& Van Zoonen, 2000:9) show that political knowledge and participation are stimulated by media exposure. Fourie $(2004: 42,96)$ puts it that the media has the pertinent duty in a democracy to provide the public specifically with political information in the light of the fact that political-knowledgeable people contribute positively to the functioning of a democracy. This, she continues, is imperative for the effective functioning of a young democracy such as South Africa's. Democracy implies a state governed by the whole population through a number of chosen leaders; characterised by freedom and independence of speech, the individual as well as the judiciary system (Nel, 2001:9; Odendal, 1994:135).

Despite the fact that there exists little doubt as to the importance of politicalknowledgeable voters for the effective functioning of a democracy (Fourie 2004:21,42,96; Delli Carpini \& Keeter in Eveland W.P., Shah, D.V., \& Kwak, N.:2003:374; Berelson, 1960:527; Hendriks et al., 2004:421), there exists a measure of concern over the feasibility of this ideal. Numerous studies have shown that citizens do not necessarily preside over alert political knowledge, but still are able to exercise political choices and motivate them (Redlawsk, 2001; Hastie \& Pennington, 1989; Baum 2003:174,181; Buckingham, 1999:172-3). This gave way to the development of the online evaluation model.

According to the on-line evaluation model, people do not actively seek out political information; learning rather takes place coincidentally. Usually people forget facts quickly, but keep a summary of their opinion on the particular issue; thus how they interpreted,/evaluated it or made sense out of it. Through this process it is easier for an individual to have/form an opinion on a person/issue without necessarily remembering all the facts that led to that opinion. This also enables individuals to make new judgments without recalling all the relevant facts, therefore streamlining the various cognitive processes involved. On-line evaluation is therefore a spontaneous, cognitive reaction formed in conjunction with an existing information schema in the specific moments that a person receives new information (Hastie \& Pennington, 1989; Baum 2003, Buckingham, 1999:172-3; Hastie \& Park, 1986; Fourie, 2004:83).

The importance of this is that the media must anticipate how to present information in an accessible manner to the media user. When political (and other) media messages are observed, people organise this information (usually subconsciously) cognitively in a particular way. These organisations of knowledge, or knowledge structures that are formed, are known as schemas in the 'schema theory' (Lau \& Sears, 1986). Information can be made more readily accessible in the individual by using certain techniques. When aspects of an issue are so important to the reader that they have bearing on the person's sense of selfhood, which includes material, social and spiritual aspects, the accessibility of the schema is increased (Lavine et al., 2000:83; Perloff, 1985:178-170). Information resonating with already existing schemas and visited recently and more frequently is also more accessible (Lavine, H., Borgida, E., \& Sullivan., J.L., 2000:99; cf. Ottati \& Wyer, 1990:199; Zaller, 1992:48-49). 
People would probably argue that women's magazines, due to their traditional nature, have a 'smaller' duty when it comes to their normative responsibility to enlighten its readers on political matters. Against the background of the on-line evaluation and schema theories, just the opposite is argued in this article.

Numerous studies have shown that worldwide women's levels of political knowledge falls short of those of their male counterparts: the so-called political 'gender gap' (Guynan, E. M., 2004:50; Gidengil, E., Goodyear-Grant, E., Nevitte, N., Blais, A. \& Nadeau, R., 2003:13; Bickerton \& Gagnon, 2004:228; Anon, 2005; Soule \& Nairne, 2006). What is of particular concern is research showed how women's levels of political knowledge have stayed relatively the same since the 1950's and 1960's to date(Soule, 2001:4). It is starting to look as though media aimed at primarily a female market might have an even bigger duty to perform.

It was also found that most women have relatively little interest in media content that focuses on what they believe to be 'male' concerns, namely the news and current events, science and matters of a documentary nature (thus including politics). The self-admitted reason for this is the fact that most women do not see the relationship between these affairs and their everyday lives and therefore deem it as less relevant to them, although they do in fact grasp the seriousness and importance of these issues (Soule 2001:4; Carter $\&$ Steiner, 2004:22). When the media gets to the point where they grasp how important it is for the average woman to understand how an issue may impact on her personally, her family and immediate environment, they can make work of getting and keeping their attention by engaging these schemas. This article holds the viewpoint that women's magazines, such as Fair Lady, are in fact uniquely positioned to activate familiar schemas and by doing so bring political information closer to the reader.

The media is indeed an extremely specialised industry in the sense that it focuses on specific target audiences and therefore caters specifically for that niche market's news needs. This is especially true of the magazine market, as Claussen (2008:338) rightly puts it:

Magazines, for instance, are the original niche media product, with magazine design and content historically and still shaped by who the audience is, and the audience sorting itself between one magazine and its competitors based on what the design and content are.

When taking into consideration that the magazine is a product that reflects the readers' culture of the day, the possibility that women's magazines might still ignore this aspect in a time where more and more women are represented in, for instance parliament, is to be questioned. South Africa jumped from 34 percent female representation before the 2009 national elections to 43 percent thereafter, resulting in a jump from 17 th to 4 th place globally regarding the representation of women in parliament. Rwanda (56 percent), Sweden (47 percent) and Cuba (43.2) are the current frontrunners (Gender Links, 2009). 
Women have played an important role in the country's politics since the advent of transformation; their participation is imperative for the country's social stability and economic progress (IFP, 2000; Baden, S., Hassim, S., \& Meintjies, S., 1999).

Against the above-mentioned background the problem investigated in this article is that women also need to be informed citizens to function effectively as citizens of the young South African democracy, but are not always interested enough in politics. Likewise, the focus of traditional women's magazines is not politics in the first instance, but they also have a normative responsibility to inform their readers about important political issues that affect their lives and are uniquely positioned to do so. In order for women's magazines to fulfil this normative responsibility the following guidelines specifically aimed at the editorial staff are proposed in this article to provide the needed information, but disguise it not to alienate the traditional woman's magazine reader:

1. Actively seek out political news items which serve the interests of women

2. Report in a balanced and fair way on political parties, non governmental organisations and the government's policy and activities pertaining to women, ecology, crime against women and other social problems, as well as women's political, legal, financial and health rights

3. Place aspects pertaining to women and their everyday lives on the foreground to create context

4. Pull/interest the reader by the use of the traditional women's magazine approach, interesting facts and/or emotional content, choice of graphics and simple, understandable writing style

5. Use the human interest approach by presenting 'ordinary' women as role models and covering well-known people's political perspectives

6. Experts should preferably be female

Using these guidelines as a base, this article investigates to what extent and how Fair Lady presented political news to her readers in 1994, 1996, 1999 and 2004, spanning the first ten years of democracy in South Africa.

\section{Research method}

Fair Lady's political news was analysed by making use of qualitative content analysis. The decision was based on the fact that this study focuses on meaning, interpretations and derivations rather than exclusively the number of reports or themes (Du Plooy, 2002:29; Verwey, 2003:161-2, 164).

The period of investigation extended from 1994 to 2004. It was chosen because political knowledge tends to increase during election times (Kenski, 2002:198). The year 1996 was also a landmark year for women with regard to political policy change, in light of the fact that abortion was legalised (Poggenpoel \& Myburgh, 2002:731; Varkey, 2000:87; Mathewes-Green, 2006; Gordon, 1999). Therefore no sample was compiled; rather the 
focus was on complete years. However, in years where editions were brought out every two weeks, only the first of every month was used for the sake of feasibility.

Political news items, the units of analysis of this study, implies the occurrence and handling of political themes (about the interaction between the state and public) in published format of any nature in the form of specified entities (like articles, reports or smaller sections of rubrics). Articles and reports that do indeed focus on women's personal empowerment, but do not relate to politics on any level, were not investigated.

During the content analysis, the researcher had to have a pattern according to which the content could be consistently investigated throughout. The set normative guidelines were used as the basis for the analysis of Fair Lady's content. Two datasheets were compiled one for measuring information from items based on a political topic and one for items merely referring to political information, but not handling it as a main theme or topic. The latter (called datasheet B) was much less comprehensive than the first (datasheet A). Datasheet A measured the political topic, in what genre it featured and then commenced asking multiple questions derived from each of the six guidelines. In the answering of these questions it was anticipated that the degree to which the specific guideline manifested in the content of the item would be determined. As they were open-ended questions, it left enough scope for interpretations, derivations and the identification of new lines of thought.

\section{Discussion of results}

\subsection{Actively seek out political news items which serve the interests of women.}

In the assessment of the degree to which this guideline manifests in the content of Fair Lady, the frequency of the coverage of political information was established as well as the number of items covering specific topics and the specific genres in which they feature.

The topics (except the last five) in Table 1 were identified from the literature and $M s$ Magazine and are regarded as topics about which women should be politically knowledgeable and which would probably interest them. Ms Magazine is a feminist women's magazine and would therefore without doubt contain political information. It could, therefore be used to determine the feasibility of the guidelines. The fact that it is not a traditional women's magazine was, however, taken into account throughout. 
Table 1: The topics and genres in how they feature in Fair Lady (1994-2004)

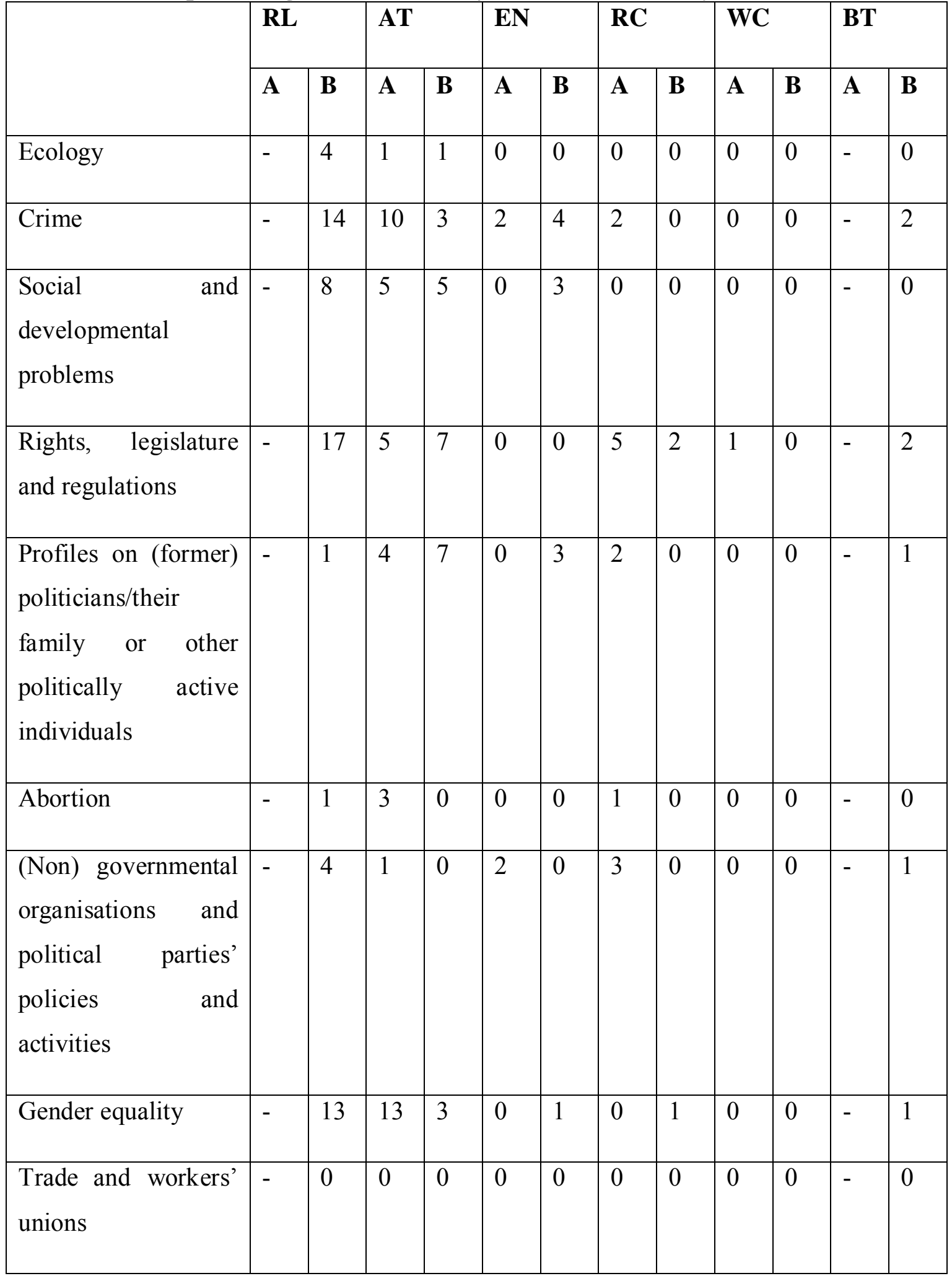




\begin{tabular}{|c|c|c|c|c|c|c|c|c|c|c|c|c|}
\hline $\begin{array}{l}\text { Women's } \\
\text { conferences }\end{array}$ & - & 0 & 0 & 0 & 0 & 0 & 0 & 0 & 0 & 0 & - & 0 \\
\hline $\begin{array}{l}\text { Democracy and post } \\
\text { apartheid*** }\end{array}$ & - & 9 & 4 & 10 & 1 & 1 & 0 & 2 & 3 & 0 & - & 2 \\
\hline $\begin{array}{l}\text { Racial and other } \\
\text { ideological } \\
\text { matters*** }\end{array}$ & - & 9 & 1 & 2 & 0 & 0 & 0 & 0 & 1 & 0 & - & 1 \\
\hline $\begin{array}{l}\text { Playing watchdog } \\
\text { over institutions*** }\end{array}$ & - & 8 & 4 & 2 & 0 & 1 & 0 & 0 & 0 & 0 & - & 0 \\
\hline Sport*** & - & 0 & 1 & 1 & 0 & 0 & 0 & 0 & 0 & 0 & - & 0 \\
\hline $\begin{array}{l}\text { International } \\
\text { politics*** (profiles } \\
\text { excluded) }\end{array}$ & - & 1 & 0 & 0 & 0 & 1 & 0 & 1 & 0 & 0 & - & 1 \\
\hline
\end{tabular}

The last five topics listed in the table (marked with $* * *$ ) were added after completion of the content analysis and are South African specific political topics found in Fair Lady.

As indicated in table 1, crime, gender (equality) and rights, legislature and regulations are the most popular topics. Crime has the element of sensation which attracts most readers. The information also teaches them about the world in which they live and enables them to have empathy with others. Rights, legislature and regulations are common because it empowers people with information that enables them to prevent or overcome problems. In line with one of its functions, the media regularly interprets complex information, for example changes in legislation, in order to create conception of the implications thereof for the reader.

It is furthermore interesting to note that by far the most items that refer to politics can be found in the category of readers' letters. The only other genre that comes close is articles. The rest of the genres contain little or no political information. There are between zero and three items in any of the genres in any given year throughout, with the exception of the editor's notes in 1999 (seven items here refer to politics) and regular columns in 2004, where nine are based on politics. The first mentioned phenomenon is ironic in the sense that 1999 as a whole had the least coverage of politics, yet at the same time the editor's notes supposedly indicate what the editorial team deem important. Even so, there are no more than three items referring to politics or more than two based on it in any of 
the other years in this genre. With regard to the second exception mentioned, there is, however, a possible explanation. The high number of regular columns (RC) in 2004 is mainly attributed to two types of topical columns only found in that specific year, entitled 'Talking About' and 'Talking Point'. The first mentioned is about well known individuals and the second about events or issues usually in the news around the time of publication.

It is clear that a wide range of topics that can be related to politics are covered. There are, however, a void with regard to the coverage of the ecology, (in instance A), abortion, trade and workers' unions, and women's conferences - none of these categories contain more than five entries in total. The recommendation is that the editorial team appoint someone to get into contact with organisations involved in the neglected topic fields; this will surely increase visibility of possible newsworthy material. The chances are, however, good that in the years after 2004 more items would have focused on the ecology, with the worldwide interest in the subject. On the other hand these articles would not necessarily have a political dimension, in spite of the fact that the worsening world ecology is a phenomenon that can only be managed effectively at political level.

In readers' letters opposition toward racism and/or positivity about the new South Africa, advocacy for a number of issues and/or objection toward others, are popular themes and show how vocal readers are about politics. The magazine's letters pages thus serve as a public platform on which the reader is able to share his/her feelings, doubts and opinions and can initiate conversations or participate in them. Readers regularly get empathy from others, which confirm their opinions and feelings and legitimise them.

\subsection{Report in a balanced and fair way on political parties, non governmental organisations and the government's policy and activities pertaining to women, ecology, crime against women and other social problems, as well as women's political, legal, financial and health rights.}

Bias, especially that of party politics, was explored to ascertain the degree to which this was guideline adhered to. Room was also left for the possibility of additional political themes.

With regard to topics, crime, gender and rights, legislation and regulations are the most popular. (See the above paragraph for a detailed discussion.) The following topics, some of which are unique to the South African political context, were also identified :

- democracy and post apartheid

- $\quad$ racial and other ideological matters

- $\quad$ playing watchdog over institutions

- $\quad$ international politics (profiles excluded) 
The items usually have a positive, hopeful and even 'proud' tone, with a few exceptions. In this sense it is not neutral and might be unbalanced in a sense, but not unlike the tone of traditional women's magazines (also see 3.5).

Regarding reporting in a fair way was adhered to throughout. There was one particular noteworthy aspect that stood out in this respect. As a rule, mention of any political parties is always done in passing when it is necessary for background/context. There is never a positive or negative inclination toward any such party. It is always mentioned in relation to a person as subject. This is in line with women's magazine tradition not to get involved with party politics so as not to alienate certain readers.

\subsection{Place aspects pertaining to women and their everyday lives on the foreground to create context.}

In this guideline's assessment, it was aimed to determine whether important everyday issues were covered and if enough contexts was created in order to 'explain' to the reader why the item was worth her while.

Fair Lady's political news items have a lot of practical advice and useful information for everyday use, in some cases whole items are based on information of such a nature. A particularly good example of this is 'Who you gonna call?' (March 2004). It focuses on empowering consumers with regard to their rights in their trading with different types of business industries.

What is, however, of more importance for this study, is the items that investigate one problematic political issue in depth and at the same time poses options for solving or handling it. The approach followed in such instances is rather to focus on issues than the individual, while the reader is encouraged to help and is usually informed how to contribute practically. In this way the woman is also involved in political problems and challenges in society. For example: 'Reading the future' (February 2004) is about the limited literacy levels of Africans and how the African literature market may be expanded to encourage this literary minority group to develop. The writer proposes interventions which the reader may act upon in her everyday life. She may, for example, ask for the indigenous section in a bookstore and act surprised when there is none. She may also choose to read books with an African theme to children, support the "No VAT On Books' campaign and volunteer to teach her blue collar workers to learn to read and write.

In the items that focus specifically on issues that marginalise women and the inhibiting of their rights and freedom, a more personal approach is followed. The information relayed, is sometimes less concrete and rather aims to create understanding for an issue/person, give life lessons, voices commentary and/or interprets messages. 'Hitting the bottle' (February 2004), for example, explains how government wanted to ban advertisements on the artificial baby-feeding industry and even regulate editorial on the subject and how this would affect mothers' everyday lives. 
Contact details are also a regular useful phenomenon because it gives the reader the means to further investigate a matter or to get involved.

Further, in a latent/underlying manner, content on readers' legal, political, financial and health rights are provided. It usually derives from changes in legislature or the denial of women's rights. There is also sporadic attention given to the physical consequence of the violation of rights or the ignorance regarding rights, as well as the possible legal consequences related to this. 'Law talk - All fired up' (2 October 1996) is about the way in which new legislature influences the relationship between a domestic worker and her employer.

The physical manifestations of creating context fall in one or more of the following categories:

- in the headline and summary deck

- introductory paragraphs

- through the utilisation of ordinary people's opinions and/or experiences

- experts' input

- studies and statistics

It goes to show that there are a number of ways in which a satisfactory level of context and conclusions are created for the reader in the dissemination of information useful in their everyday lives.

\subsection{Pull/interest the reader by the use of the traditional women's magazine approach, interesting facts and/or emotional content, choice of graphics and simple, understandable writing style.}

Here the aim was to determine whether these aspects were at all incorporated in the presentation of political items. The guideline will be divided into relevant sections:

\section{- Traditional women's magazine approach}

In a study investigating the success recipe of the oldest magazine in Russia called Rabotnitsa, Tolstikova (2004) it was concluded that "[i]n Rabotnitsa, Soviet women found a friend, an adviser, a consultant, and an entertainer". It may be concluded in this study that Fair Lady readers are looking for the same.

It is important to present politics in the same tone as other items because of the fact that it is indeed this tone, so unique to women's magazines and familiar to the reader, which attracts the reader because she identifies with it. More than half of the items followed ordinary/expected approaches, which is important to attract the reader's attention on a (according to her) coincidental way. 
It appears as though the underlying 'ideology' of the women's magazine determines the underlying idea of basically all the content. It is, in line with the traditional style of women's magazines, to act as friend. A good friend warns, helps, entertains and supports. The focus of most of the political items is on one or a combination of these aspects.

It regularly focuses on aspects of women's lives not covered by the mainstream media, as clearly indicated by 'The invisible sex' (11 December 1996) - an investigation into the oppression of women of Afghanistan (Rowley, 1996:55):

"And the women have been ordered off the streets ..." A tiny sentence tucked away in the news reports - just a few words allotted to the fate of tens of thousands of people. In Kabul half the population is now effectively under house arrest because of their sex.

Further, the emphasis in most items that are political in nature, relates to the specific topic under discussion. Fair Lady therefore, in general, follows a traditional women's magazine informing style in the presentation of politics. She is on the woman's side, without going in against the ethical principles of fair and balanced reporting, and regularly advocates the equal treatment toward and rights for women. In contrast with traditional style, however, it does look at very serious topics in a particularly critical manner, but still in the interest of the reader.

In 'Rape - trial by media' (March 2004), for example, the media's handling of a high profile rape case is discussed in detail. South Africans Salomé Isaacs, an AIDS activist, and Siraj Desai, a judge, were in India at a social forum representing the country. Isaacs alleged that raped her on the trip, but dropped the charges three days later. A media circus erupted after the event - gatekeepers all wanted to explain what exactly happened and mostly speculated that the charges were false. The article thus criticised the media's handling of the case as Isaacs was further victimised by the press coverage thereof according to the article work against rape was put back about 20 years.

- Simple, understandable writing style

Slotting in with the familiar style of women's magazines, concepts outside of the normal field of women's experience are not used without being clearly defined. New concepts are usually restricted to new legislature and regulations. 'Talking point - Redefining rape' (January 2004), is about new laws regarding rape - the new definition thereof as well as the practical implications flowing from the redefinition.

The writing style itself also engaged the reader by the use of: positive and constructive messages; intimate/personal tone; column writers' unique voices; humour; creative writing style and in selected instances diary-style and the use of initial offence.

\section{- Use of graphics}


Graphics are one of the most important aspects used to attract the reader's attention. It adds value to the visual framing of a story, especially in a medium usually read by women for self invigoration. The ways in which it is used in Fair Lady in general, can be found under one of the following categorisations:

- $\quad$ identification of people involved in a story - key personalities

- $\quad$ one or more persons and/or their actions and/or the setting/scene under discussion

- $\quad$ an abstract idea or concept

- $\quad$ the repetition of graphics for physical coherence throughout the item

- well-known/recognisable people

- $\quad$ violence - an extreme form of action

- $\quad$ emotion being portrayed or elicited from the viewer

- $\quad$ exotic/unusual/novel images

- humoristic illustrations

- collages

- $\quad$ the different types as noted here in combination for contrast

'The waiting game' (November 2004), is about waiters' rights and the correlating responsibilities of restaurant owners. There is an interesting full page photo of a woman's upper body, holding a plate of food (an example of concept graphics). The last two pages have smallish photos of five waiters' faces who were asked to share their work experience (an example of the identification of key personalities, in this case rather like a traditional vox pop). In Black pack (January 2004), about racism in Hollywood, graphics are used effectively as altogether 20 coloured celebrities from Oprah Winfrey to Will Smith are combined over more than one page. They are all attractive people with very well known faces.

In a few instances more effort could have gone into the selection of graphics. Of rockey roads and democracy (April 2004) is about the Johannesburg suburb Yeoville as a metaphor for the political development phases through which South Africa went. The theme and its presentation is therefore very meaningful, even more so in the light of the distinctly creative and personal writing style. The graphics, however, do not add to the appeal set by the other elements of the article. There are only two rather small photos within the four copy pages - one of a musician and one of the buildings in Rockeystreet, the main street of activity in Yeoville. The reader is probably very curious about how the suburb looked in its golden years as described in the article and indeed how it looks today, especially in light of the fact that the writer of the article insinuates that the development in Yeoville signals that of the rest of the country beforehand. The main character in the writer's story, a friend of his named Reshada who has been staying in Yeoville through good and bad times, is also not shown. There are, however, lots of descriptions relating to her and her home. The human interest element could therefore have manifested more strongly in a visual sense and attracted the reader even more.

\section{- Interesting facts and/or emotional content}


There are uncountable interesting facts pertaining to people, their activities and relationships on the one hand and scientific facts on the other. Rule of the red-hot mammas (9 February 1994) is particularly packed with interesting information because the topic, about a matriarchal community in South America where women's plumpness and sexual assertiveness is celebrated, lends itself to the inclusion of mainly unusual information. It is further interesting that the only women for whom it is acceptable to be thin, is the 'curandera witches'. They are rather like the South African sangomas. The phenomenon is interesting as it is indicative of the fact that acceptable standards for gender roles not only vary from one country or community to the next, but also within a particular community.

According to the schema theory, emotional messages are used to increase retention of messages in media users as it catches their attention and helps them to better understand the political context (Baum, 2003). Furthermore people regularly save emotional evaluations of the cognitive experience they had while reading the particular information, which might be recalled later. Emotion and cognition influence each other and are used to form or change an attitude (Marcus, 1991; Way \& Masters, 1996).

In Fair Lady's case, emotions such as fear, desperation, sadness, suffering, anger, indignation, frustration, empathy/sympathy and nostalgia are described or shown to the reader. What is of particular importance, is the way Fair Lady apparently tries to elicit emotions from the reader and in this process probably tries to work greater involvement and interest from the part of the reader. These emotions include: nation pride/patriotism, empathy, shock, female pride and inspiration, usually in conjunction with feelings of empowerment.

The silent scream (10 November 1999) describes the tale of a woman who underwent an illegal abortion. The main reason for her choice was her fear of unleashing a custody battle with the biological father. From this example, it shows clearly that no researcher can accurately determine how the description of a subject's emotions may influence those of the reader, as a wide array of emotions may occur in the reader. In this example, some readers may have no sympathy with this particular subject and feel no identification with her described emotions of fear, confusion and desperation. She admits it herself at the beginning of the article: "My story will shock you. It may move you. It may even disgust you, but it will ring true' (Anonymous, 1999:46).

\subsection{Use the human interest approach by presenting 'ordinary' women as role models and covering well-known people's political perspectives.}

The aim here was to search for the incorporation of ordinary people's stories with which the reader could relate. Well-known individuals' political perspectives were also uncovered seeing that it would probably make the item more appealing to a number of readers, thus increasing the probability of important information 'coincidentally reaching their schemas. 
Most of the items investigated in Fair Lady followed a human interest approach. The human interest angle was executed by either focusing on a particular instance and brings a current affair into relation with it, or discussing an issue/event and then attaching a person's story to it to illustrate it. Vox pops are used sporadically, as well as diary style, writer's columns with political themes and of course profiles. What do men really think about women at work? (12 July 1996) is about jobgender and mainly based on the opinions of men on women's value and success since their advent in the work place. In A week against guns (9 June 1999) diary style is used to convey the experiences of British actress Helen Mirren during her anti-violence tour through South Africa in a unique way.

However, Fair Lady has very few examples where well-known people's political perspectives are incorporated. In the instances where it does feature, it is usually done in conjunction with those of ordinary people. There are, indeed, a number of cases where the integration of prominent people's views would have given the item more impact, thus strengthening the item's capacity to get and keep the reader's attention. One of the few exceptions is Female circumcision: a twentieth century atrocity (7 August 1996) about supermodel Waris Dirie's perspectives on female circumcision, or female genital mutilation, as some human rights activists describe it. She is very outspoken in her perspectives as she experienced the practice first hand during her childhood: 'This custom has nothing to do with religion. Neither the Koran nor the Bible mentions it. Men invented it so that sex is just for men... It's cruel, it's unfair, it's humiliating, it's unacceptable, it changes your whole life' (Fitz-Patrick, 1996:47).

Ordinary people's tales of political emancipation are also scarce as well as profiles on political affiliated personas. There were in total only four profiles on politicians and/or their family members. Of those, only one is on a South African. In order to help the readers to get to know the local politicians better, thus expanding their schemas on them, more coverage needs to be given to public servants.

These are therefore definite areas for possible improvement.

\subsection{Experts should preferably be female.}

The number of sources was counted. It was noted who were female and male as well as how many were experts.

The total amount of sources in the investigated literature from Fair Lady that was based on a political theme amounts to 299. Altogether 56 percent of the sources are female while 2 percent of the total sources are female experts. Male sources make up 40 percent of the total quantity; 23 percent of the grand total is male experts. In other words, approximately six out of ten sources belong to the female gender, while about four out of 10 are male. Apart from this, just short of one quarter of the sources is male experts while exactly one quarter is female experts. More female sources were in fact used, but percentage wise they were used far less for their expertise than men. 
More consideration should therefore be taken to frame women as experts to enhance the image of women being experts on a variety of fields, especially those traditionally male dominated. As stated in the introduction women's magazines do, after all, help form gender roles in society.

\section{Conclusion}

To answer the specific question posed in this article: 'to what degree, and how, are politics portrayed in specific genres in Fair Lady', the following may be surmised:

Politics are high on the agenda of Fair Lady, as a traditional women's magazine. The topics and approaches are generally interesting and would probably get the reader's attention. Throughout the reader is provided with enough useful information, context and ideas to base conclusions on. It is therefore in line with the schema and on-line evaluation theories.

Where definite conclusions are indeed rendered, the purpose is apparently not to tell the reader what to think; rather what to think about. These results are in line with the agenda setting theory. Fair Lady is not involved with party politics; rather it is consumed with the enhancement of society and more specifically women. It is positive and inspiring, yet sometimes particularly critical. In other words they fulfil a watchdog function unusual for a traditional women's magazine.

Throughout, the journalists' writing style is professional and supports the message. Together with the application of graphics in general, it attracts attention. Graphics could however have been more thought through in certain instances, as well as the use of female expert sources, well known people's political perspectives, ordinary people's stories of political emancipation and profiles on political-affiliated people from South Africa.

The human interest approach is used throughout as well as interesting facts, emotional content and useful information, which make infotainment the dominant way of presenting news. This is indeed in line with the expectations set by the theoretical approach to this study. In general Fair Lady fulfils her function as 'information relayer to' and 'educator of' women by covering enough political items and referring to enough political information on their agenda in an entertaining way to get readers' attention and extend her schemas in the process, although some topics and genres need more attention.

Women's magazines actually act in a dysfunctional way when they perpetually present gender stereotypes as normal. It is especially harmful when they contribute to inhibiting women from living expressively and assertively. On such a charge, Fair Lady is, however, not guilty. It is concluded that the magazine deems politics as important and incorporates it on its agenda to provide readers with necessary political information which they might not otherwise attain. Fair Lady overcomes the fact that politics do not traditionally feature in women's magazines by taking care in attracting and keeping readers' attention to political items. The publication (especially in 2004) can be held up 
as an example to other women's magazines, trying to fulfil their function as a medium to educate and inform readers while at the same time not alienating the entertainmentseekers.

The importance of this is illustrated by the Cuban poet Jose Martí (as quoted by Grunig, 1989:125) when he made the following statement pleading for educational opportunities for women:

[Education is] something which will secure their happiness, because enhancing their minds through solid studies, they will live on a par with men as comrades, not at their feet like beautiful toys, and because of her self-sufficiency, a woman will not feel hurried to attach herself - as a reed to a wall - to the first passer-by, but instead, she will ponder and decide, leaving aside the rogues and liars and choosing the industrious and sincere.

\section{References}

Anon. The silent scream. Fair Lady, $10^{\text {th }}$ of November 1999

Anon. Talking point - redefining rape. Fair Lady, January, 2004

Anon. 2005. Is there a political gender gap in Uganda? Available on the World Wide Web:

http://www.afrobarometer.org/papers/AfrobriefNo16.pdf (accessed 200709-17)

Baden, S, Hassim, S. \& Meintjies, S. 1999. Country gender profile: South Africa. Available on the World Wide Web: http://womensnet.org.za/links/genderpr.htm (accessed 2008-02-20)

Baum, MA. 2003. Soft news and political knowledge: evidence of absence or absence of evidence? Political Communication, 20:173-190

Berelson, B. 1960. Communications and public opinion. In Schramm, W.L. (ed). 1960. Mass communications: a book of readings. 2 nd ed.

Urbana: University of Illinois Press. pp.527-543 
Berger, AA. 1995. Essentials of mass communication theory. Thousand Oaks: Sage Publications. p 208

Bickerton, J. \& Gagnon, A.G. 2004. Canadian politics. books.google.com (accessed: 2007-09-17)

Bishop, B. The waiting game. Fair Lady, November 2004

Black, ER. 1982. Politics and the news - the political functions of the mass media.Toronto, Durban: Butterworth. p272

Buckingham, D. 1999. Young people, politics and news media: beyond political socialisation. Oxford Review of Education, 25(1\&2):171-184

Burdett, S. Who you gonna call? Fair Lady, March 2004

Carter, C. \& Steiner, L. 2004. Mapping the contested terrain of media and gender research. In Carter, C. \& Steiner, L. (eds). Critical readings: media and gender. Maidenhead: Open University Press. pp.11-37

Claussen, D.S. 2008. Editor's note. Journalism and Mass Communication Educator, 62(4):337-340

De Beer, A.S. 1998. Mass communication in society. In De Beer, A.S., (ed). Mass media towards the millennium. The South African handbook of mass communication. Pretoria: Van Schaik. pp.5-31

Du Plooy, G.M. 2002. Communication research - techniques, methods and applications. Lansdowne: Juta. p 379

Durandt, A. Law talk - all fired up. Fair Lady, 2 October 1996

Eveland, W.P., Shah, D.V. \& Kwak, N. 2003. Assessing causality in the cognitive mediation model - a panel study of motivations, information processing and learning during campaign 2000. Communication Research, 30(4):359-386

2010 Vol 4 (2)

Fitz-Patrick, E. Female circumcision: a twentieth century atrocity. Fair Lady, 7 August 1996 
Fourie, L.M. 2004. Partybeheerde kommunikasie in die Noordwesprovinsie tydens die Suid-Afrikaanse algemene verkiesing van 1999. Potchefstroom: North-West University. (Thesis: PhD). p484

Froneman, J.D., Swanepoel, T. \& Van Rooyen, G.M. 2005.

Handboek vir joernalistiek in Suid-Afrika. 3de uitgawe. Potchefstroom: Die skrywers. p. 230

Gender Links. 2009. http://www.genderlinks.org.za/article.php?a_id=3819 (accessed: 2009-09-7)

Gidengil, E., Goodyear-Grant, E., Nevitte, N., Blais., A. \& Nadeau, R. 2003. Gender, knowledge and social capital. Paper prepared for the conference on Gender and Social Capital held at the University of Manitoba, May 2003

Grunig, LS. 1989. The 'glass ceiling' effect on mass communication students. In Creedon, P.J., (ed). Women in mass communication: challenging gender values. Newbury Park, Calif: Sage Publications. pp.83111

Guynan, EM. 2004. The gender gap in political knowledge: a comparison of political knowledge levels in the United States, Canada, and Great Britain. Louisiana: Louisiana State University. (Thesis: MA). p68

Hastie, R. \& Park, B. 1986. The relationship between memory and judgment depends on whether the judgment task is memory-based or on-line. Psychological Review, 93(3):258-268

Hastie, R. \& Pennington, N. 1989. Notes on the distinction between memory-bases versus on-line jugements. In Bassill, N. (eds). On-line cognition in person perception. Hillsdale: Erlbaum. p.1-17

Heith, D.J. 2005. Reaching women: soft media in the 2004 presidential election cycle. Paper presented at the American Political Science Association Annual Meeting, Washington DC

Hendriks Vettehen, P.G.J., Hagemann, C.P.M. \& Van Snippenburg, L.B. 
2004. Political knowledge and media use in the Netherlands. European Sociological Review, 20(5):415-424

Hillsdale: Lawrence Erlbaum. pp.347-366

IFP. 2000. Women issues policy. Available on the World Wide Web: http://www.ifp.org.za/Policies/polwomen.htm (accessed 2008-02-20 )

Inness, S.A. 2004. Pretty tough: the cult of femininity in women's magazines. In Carter, C. \& Steiner, L. (eds). Critical readings: media and gender. Maidenhead: Open University Press. pp.123-142

Kenski, K. 2002. Testing political knowledge: should knowledge questions use two response categories or four? International Journal of Public Opinion, 15(2):192-200

Knowler, W. Hitting the bottle. Fair Lady, February 2004

Laswell, H.D. 1960. The structure and function of communication in society. In Schramm, W.L, (ed). 1960. Mass communications: a book of readings. 2nd ed. Urbana: University of Illinois Press. pp.513-526

Lau, R.R. \& Sears, D.O. 1986. Social cognition and political cognition: the past, the present and the future. In Lau, R.R. \& Sears, D.O. (eds). Political cognition: the $19^{\text {th }}$ annual Carnegie Symposium on cognition. NJ

Lavine, H., Borgida, E. \& Sullivan, J.L. 2000. On the relationship between attitude involvement and attitude accessibility: toward a cognitivemotivational model of political information processing. Political psychology, 21(1):81-106

Lazarsfeld, P.F. \& Merton, R.K. 1960. Mass communication, popular taste and organized social action. In Schramm, W.L, (ed). 1960. Mass communications: a book of readings. 2nd ed. Urbana: University of Illinois Press. pp.429-512

2010 Vol 4 (2)

Le Masurier, M. 2009. Desiring the (popular feminist) reader: letters to 
Cleo during the second wave. Media International Australia, 131:106-116

Marcus, G.E. 1991. Emotions and politics: hot cognitions and the rediscovery of passion. Social science information, 30(2):195-761

Mathewes-Green, F. 2006. Abortion: women's rights...and wrongs. http://www.feministsforlife.org/FFL_topics/after/rtnwrfmg.htm (accessed: 2006-10-9)

Narunsky-Laden, S. 2007. Consumer magazines in South Africa and Israel. Journalism Studies, 8(4):595-612

Malan, R. Of rockey roads and democracy. Fair Lady, April 2004

McQuail, D. 2000. McQuail's mass communication theory. 4th (ed). London: Sage, p542

Mirren, H. A week against guns. Fair Lady, 9 June 1999

Odendal, F.F. HAT: Verklarende handwoordeboek van die Afrikaanse taal. 1994. 3de uitgawe. Midrand: Perskor. p.1295

Oosthuizen, L.M. 2003. Media and terrorism. In, Fourie, P.J, (ed). 2003. Volume I: Media studies: institutions, theories and issues. Lansdowne: Juta. pp.538-567

Ottati, V.C. \& Wyer, R.S. jr. 1990. The cognitive mediators of political choice: toward a comprehensive model of political information processing. In Ferejohn, J.A. \& Kuklinski, J.H. (eds). Information and democratic processes. Urbana: University of Illinois Press. pp.186-218

Perloff, R.M. 1985. Personal relevance and campaign information seeking: a cognitive response-based approach. In: Kraus, S. \& Perloff, R.M, (eds). Mass media and political thought: an information-processing approach. London: Sage. pp.177-200

2010 Vol 4 (2)

Poggenpoel, M. \& Myburgh, C.P.H. 2002. The developmental implications of a termination of pregnancy on adolescents with reference to the girl and 
her partner. Education, 122(4):731-742

Redlawsk, D.P. 2001. You must remember this: a test of the one-line model of voting. Journal of politics, 63(1):29-59

Ronge, B. Black pack. Fair Lady, January 2004

Rowley, J. The invisible sex. Fair Lady, 11 December 1996

Rutter, K. Rape - trial by media. Fair Lady, March 2004

Shakespeare, J. Rule of the red-hot mammas. Fair Lady, 9 February 1994

Sotirovic, M. \& McLeod, J.M. 2001. Values, communication behavior, and political participation. Political Communication, 18:273-300

Soule, S. 2001. Will they engage? Political knowledge, participation and attitudes of generations X and Y. Available on the World Wide Web: http:www.civiced.org/research_engage.pdf(accessed 2006-03-14)

Soule, S. \& Nairne, J. 2006. Are Girls Checking Out? Gender and political socialization in transitioning democracies. A paper presented at the Midwestern Political Science Meeting, Chicago, April 19-23, 2006

Sreberny, A. \& Van Zoonen, L. 2000. Introduction. In Sreberny, A. \& Van Zoonen, L. (eds). 2000. Gender, politics and communication. Cresskill, NJ: Hampton Press. pp 1-19

Tolstikova, N. 2004. Rabotnitsa: The Paradoxical Success of a Soviet Women's Magazine. Journalism History, 30(3):131-140

Retief, J. 2002. Media ethics: an introduction to responsible journalism. Oxford; Cape Town: Oxford University Press. p261

Varkey, S.J. 2000. Abortion services in South Africa: available yet not accessible to all. International Family Planning Perspectives, 26 (2):87-88

Verwey, S. 2003. Content analysis. In Rossouw, D, (ed). 2003. Intellectual 
tools: skills for the human sciences. Pretoria: Van Schaik. pp.160-168

Vidal, M. What do men really think about women at work? Fair Lady, 12 July 1996

Way, B.M. \& Masters, R.D. 1996. Emotion and cognition in political information processing. Journal of communication, 64(3):48-65

Wilson, S. Reading the future. Fair Lady, February 2004

Zaller, J.R. 1992. The nature and origins of mass opinion. Cambridge: Cambridge University Press 